L.V. Karabanova ${ }^{1}$, L.A. Honcharova ${ }^{1}$, V.I. Sapsay ${ }^{2}$, D.O. Klymchuk ${ }^{2}$

\title{
SYNTHESIS, MORPHOLOGY AND THERMAL PROPERTIES OF THE POSS-CONTAINING POLYURETHANE NANOCOMPOSITES
}

\author{
${ }^{1}$ Institute of Macromolecular Chemistry of National Academy of Sciences of Ukraine \\ 48, Kharkov Road, Kyiv, 02160, Ukraine, e-mail: lyudmyla karaban@ukr.net \\ ${ }^{2}$ M.G. Kholodny Institute of Botany of National Academy of Sciences of Ukraine \\ 2, Tereshchenkivs 'ka Str., Kyiv, 01601, Ukraine
}

\begin{abstract}
A series of nanocomposites based on polyurethane matrix (PU) have been synthesized using 1,2-propanediolisobutyl polyhedral oligomeric silsesquioxanes (POSS) as functionalized nanofiller. The effect of POSS content (0-10\% by weight) on the structure and properties of the created nanocomposites have been investigated. The polymer matrix (PU network) was synthesized from adduct of trimethylolpropane (TMP) and toluene 2,4-diisocyanate (TDI), and oligoetherglycol with $M w=5000 \mathrm{~g} / \mathrm{mol}^{-1}$. FTIR analysis was used for investigation of 1,2-propanediolisobutyl-POSS incorporation possibility into PU matrix. The FTIR spectra of neat POSS, neat TDI-TMP adduct and model system adduct + POSS before curing and after curing were analyzed. The FTIR-ATR data obtained evidence that the POSS structure is chemically incorporated into the PU matrix during process of nanocomposites preparation. The thermal behaviour of POSS-containing nanocomposites by differential scanning calorimetry (DSC) and thermogravimetric analysis (TGA) was investigated. From the DSC data the glass transition temperature $\left(T_{g}\right)$ of the nanocomposites was found to be increased with increasing of POSS content. Overall the results of thermal properties investigation of POSS-containing nanocomposites demonstrate that the created nanocomposites are significantly more thermally stable in compare with native matrix. The morphology of POSS-containing nanocomposites by SEM was analyzed. The incorporation of the POSS nanoparticles into PU matrix was found results in the formation of more ordered structure. Consequently the POSS introduced into PU matrix acts as nanostructuring agent. As a result the nanocomposites with more ordered structure are formed, so leading to obtaining of materials with improved thermal stability.
\end{abstract}

Keywords: polyurethane, polyhedral oligomeric silsesquioxanes, nanocomposite, morphology, Fourier transform infrared spectroscopy, differential scanning calorimetry, thermogravimetric analysis

\section{INTRODUCTION}

Nanocomposites are a unique class of materials where a little quantity of nanofillers can significantly improve their properties [1-5]. Polyurethanes (PUs) are often used as polymer matrices for nanocomposites preparation due to their wide variety of physical and chemical properties [6-9]. The incorporation of polyhedral oligomeric silsesquioxane (POSS) macromer into the polyurethane matrix was found results in improving of the permeability of gas transport [10], increasing of the conduction and the permittivity [11]. The addition of POSS into the PU's polymers leads to enhancement of their thermal stability $[12,13]$, also to improving of the mechanical properties $[14,15]$ due to the reinforcement effect of the nanoparticles. The increasing of resistance of the nanocomposites against oxidation was also detected by authors $[14,16]$ due to incorporation of POSS to the systems. These favorable effects are evident mainly when the functionalized POSS particles are integrated into polymer chains via a chemical reaction.

In our study, 1,2-propanediolisobutyl-POSS (POSS) was used as a functionalized nanofiller for PU matrix. The presence of two reactive hydroxy groups in peripheral substituent of POSS allows it to react with diisocyanates so resulting in embedding of the POSS particles into the main polymer chaing of the nanocomposites [17-19].

The objective of the present study was the creation of nanocomposites based on polyurethane matrix and 1,2-propanediolisobutyl polyhedral oligomeric silsesquioxane (POSS), and investigation of the effects induced by the POSS content on the morphology and thermal properties of the nanocomposites.

\section{MATERIALS}

1,2-propanediolisobutyl polyhedral oligomeric silsesquioxane (POSS) was purchased from SigmaAldrich Inc. Trimethylolpropane (TMP) and 
toluene 2,4-diisocyanate (TDI) were obtained from Merck. The reagents were of high purity and used as received. The oligoetherglycol with $M \mathrm{~W}=5.000 \mathrm{~g} / \mathrm{mol}^{-1}$ (Laprol 5003) was obtained from commercial sources and dried with liquid nitrogen under vacuum at $75-80^{\circ} \mathrm{C}$ for $5 \mathrm{~h}$ before use. Ethyl acetate was used as a solvent and its purification was done by distillation in vacuum.

The molecular structures of neat components constituents of the nanocomposites are presented below.
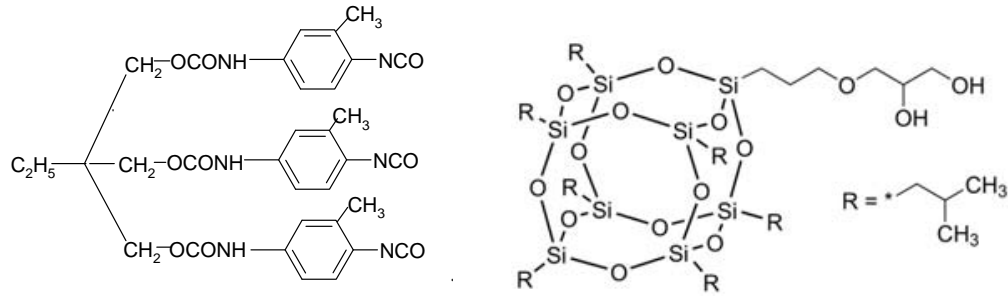

POSS

Adduct TMP-TDI

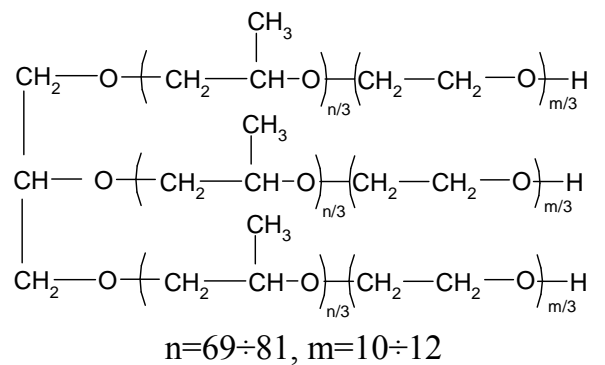

Laprol 5003

\section{Preparation of PU/POSS nanocomposites.}

PU network used as polymer matrix was synthesized by two-step polymerization. In the first stage, the adduct of trimethylolpropane with toluene 2,4-diisocyanate (the adduct TMP-TDI) was obtained as described before [20]. Second step was the synthesis of three-dimensional polyurethane. Polyurethane network was obtained from a mixture of Laprol 5003 and adduct TMP/TDI (ratio 1:2 g-eq.) at $80{ }^{\circ} \mathrm{C}$ in nitrogen atmosphere. POSS (1 or 10 wt. \%) was added as a functionalized nanofiller at the second stage of PU network synthesis. The stoichiometric ratio $\mathrm{NCO} / \mathrm{OH}=1.5 / 1$ was in all cases. The mixture was poured out on Petri dishes and cured at $70^{\circ} \mathrm{C}$ for $2 \mathrm{~h}$ and post-cured at $80^{\circ} \mathrm{C}$ for $24 \mathrm{~h}$. The obtained nanocomposite films with $\sim 1 \mathrm{~mm}$ thickness were post-cured for $2 \mathrm{~h}$ at $100{ }^{\circ} \mathrm{C}$ and then were held at $80^{\circ} \mathrm{C}$ for $36 \mathrm{~h}$ in vacuum $10^{-5} \mathrm{~Pa}$ to remove residual solvent. The nanocomposites were named PUX, where $\mathrm{X}$ denotes the content of POSS in the samples. For example, PU1 indicates that the POSS content in the nanocomposite is $1 \%$ by weight.

Neat PU also was synthesized for investigation and comparison of the results.

\section{METHODS}

Fourier transform infrared spectroscopy (FTIR). FTIR spectra of neat POSS, neat adduct TMP-TDI and model adduct+POSS (see below for details) were recorded using a TENSOR 37 FT-IR spectrometer (BRUKER, USA, Germany) in the spectral range of $4000-400 \mathrm{~cm}^{-1}$ (with resolution of
$0.8 \mathrm{~cm}^{-1}$ ). The samples (thin films) of PU, PU1, and PU10 were presented in the ATR module.

Differential scanning calorimetry (DSC). DSC was undertaken using a TA Instruments Q1000, on samples (cut thin film samples) of $10-15 \mathrm{mg}$ in hermetically-sealed aluminium pans. Experiments were conducted at the heating rate of $20{ }^{\circ} \mathrm{C} \mathrm{min}^{-1}$ in the temperature range $-90{ }^{\circ} \mathrm{C}$ to $200{ }^{\circ} \mathrm{C}$ under nitrogen. The glass transition temperature $\left(T_{g}\right)$ was taken as the midpoint of the curve at the change in heat capacity.

Thermogravimetric analysis (TGA). TGA was undertaken using a TA Instruments Q500 in hermetically-sealed aluminium pans. In a dry nitrogen atmosphere, the samples (about 5-6 mg) were heated from ambient temperature to $700{ }^{\circ} \mathrm{C}$ at the heating rate of $20^{\circ} \mathrm{C} \mathrm{min}-1$. The initial thermal degradation temperature was taken as the onset temperature at which a mass loss of $5 \mathrm{wt} \%$ occurs.

Scanning electron microscopy (SEM). Scanning electron microscopy (SEM) was performed on a JEOL JSM 6060 LA (Tokyo, Japan) at the accelerating voltage of $30 \mathrm{kV}$ and using a detector of secondary electrons. The samples were cut into strips, before being submerged in liquid nitrogen for $5 \mathrm{~min}$ and fractured as quickly as possible. Then the samples were warmed to room temperature and fixed to an SEM stub. The fracture surface of samples was coated with gold in vacuum to prevent accumulation of static charge and to increase the resolution. All measurements were done at $20{ }^{\circ} \mathrm{C}$ and at magnification of $\times 15000$. 


\section{RESULTS AND DISCUSSION}

\section{FTIR analysis of incorporation of 1,2-propanediolisobutyl-POSS into PU matrix.}

A model system adduct+POSS was created by mixing of the adduct of TDI-TMP and POSS in the molar ratio $\mathrm{NCO} / \mathrm{OH}=1.5 / 1$ for the FTIR investigation of the possibility of POSS incorporation into PU matrix. This model allows us to investigate the potential of the hydroxy groups of POSS to react with diisocyanates of adduct TDI-TMP in our system. A given amount of POSS (10 wt. \%) was dissolved in ethyl acetate and added to the adduct. The composition was carefully mixed and coated in glass $\mathrm{NaCl}$. The mixture was cured at the $80{ }^{\circ} \mathrm{C}$ within 3 days.

In Fig. 1 the FTIR spectra of neat POSS, neat TDI-TMP adduct, and model system adduct+POSS before curing and after curing are presented.

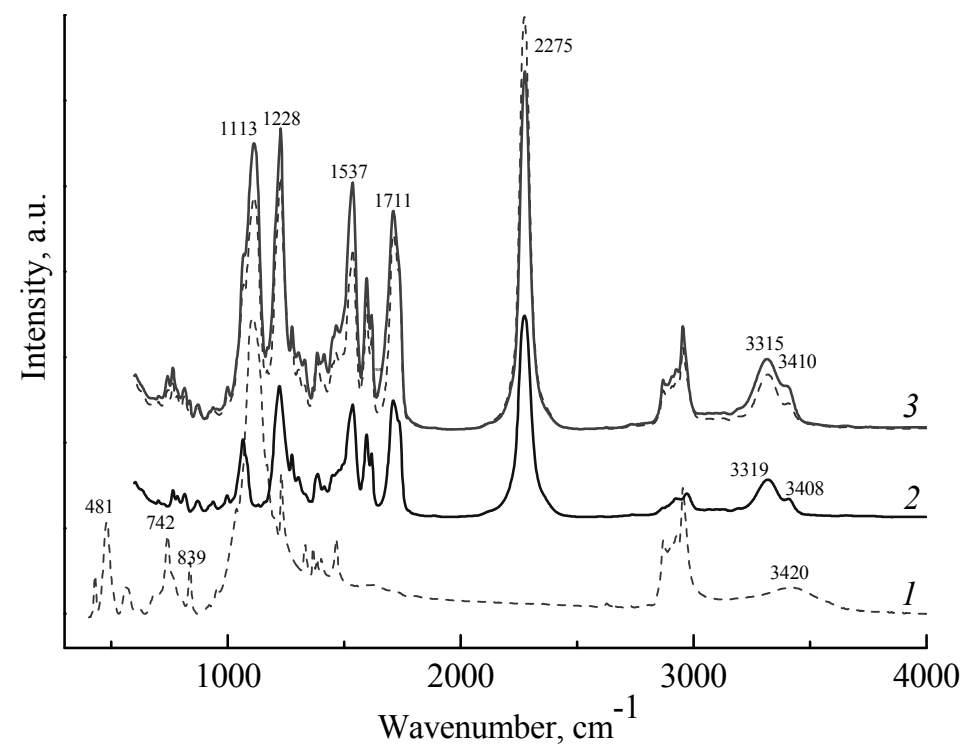

Fig. 1. FTIR spectra of: 1 - neat POSS; 2 - neat adduct TDI-TMP; 3 - model system adduct+POSS before (dot) and after curing (straight line)

In the FTIR spectrum of POSS the strong absorption band at $1108 \mathrm{~cm}^{-1}$ is observed (Fig. 1, curve 1) which could be attributed to the asymmetric stretching mode of $v_{\text {as }}(\mathrm{Si}-\mathrm{O}-\mathrm{Si})$ in caged structure [21-23] and it is always accompanied with the corresponding symmetric stretching counterpart mode $v_{\mathrm{s}}(\mathrm{Si}-\mathrm{O}-\mathrm{Si})$ in the spectral region from 400 to $480 \mathrm{~cm}^{-1}$ (at $481 \mathrm{~cm}^{-1}$ ) $[21,22,24,25]$ and corresponding bending vibrations $\delta_{\mathrm{s}}(\mathrm{O}-\mathrm{Si}-\mathrm{O})$ at $565 \mathrm{~cm}^{-1}[25,26]$. The band at $742 \mathrm{~cm}^{-1}$ is attributed to the stretching vibration in the $\mathrm{Si}-\mathrm{C}\left(\mathrm{H}_{2}\right)$ isobutyl groups of POSS $[25,27]$ and accompanied by $\mathrm{CH}_{2}$ (2871 and $\left.2926 \mathrm{~cm}^{-1}\right)$ and $\mathrm{CH}_{3} \quad\left(2908\right.$ and $\left.2955 \mathrm{~cm}^{-1}\right)$ stretching [28] and corresponding deformational modes $\left(1465,1402,1384,1230\right.$, and $\left.839 \mathrm{~cm}^{-1}\right)$ $[23,25,29]$. The broad band at $3420 \mathrm{~cm}^{-1}$ is attributed to the stretching mode of $v(\mathrm{OH})$ [30].

The characteristics of absorption bands of neat adduct (urethane units peaks) (Fig. 1, curve 2) are at 3408 (free $\mathrm{N}-\mathrm{H}$ stretching), 3319 (hydrogen- bonded $\mathrm{N}-\mathrm{H}$ stretching), 1730 (free $\mathrm{C}-\mathrm{O}$ stretching), 1711 (H-bonded C-O stretching), 1537 $\left(\mathrm{N}-\mathrm{H}\right.$ bending), and $1233 \mathrm{~cm}^{-1} \quad(\mathrm{~N}-\mathrm{CO}-\mathrm{O}$ asymmetric stretching) [29,31]. The broad bands in the range from 2856 to $2951 \mathrm{~cm}^{-1}$ are assigned to the saturated $\mathrm{C}-\mathrm{H}$ symmetric and asymmetric stretching vibrations of methylene groups [29].

In Fig. 1. (curve 3) the spectrum of model system adduct+POSS before (dot) and after curing (straight line) are presented. We could observe that the band of isocyanate group (-NCO stretching, $2275 \mathrm{~cm}^{-1}$ ) of the model adduct+POSS decreased with the curing process. Conversely, urethane units bands increased and redistributed. So, we can conclude that the additional urethane linkages are formed in the model adduct+POSS that means the hydroxyl groups of POSS are capable to react with diisocyanates of adduct TDI-TMP in our system.

The proposed structure of cured model adduct of TDI-TMP+POSS is shown in Fig. 2. 
FTIR-ATR analysis. Chemical structure of the POSS-containing nanocomposites.

In Fig. 3 the FTIR-ATR spectra of the nanocomposite films with different POSS content after curing are presented. The isocyanate band at $2275 \mathrm{~cm}^{-1}$ corresponding to the $-\mathrm{NCO}$ stretching vibrations (Fig. 2, curves 2,3) has completely disappeared when the curing process finalizes in the neat PU and also in the nanocomposites (Fig. 3, curves 1-3).

For the POSS-containing nanocomposites, PU1 and PU10 (Fig. 3, curves 2 and 3), not only the characteristic bands of urethane units (see above), but also the absorption bands at 1108 and $743 \mathrm{~cm}^{-1}$ for $\mathrm{Si}-\mathrm{O}-\mathrm{Si}$ and $\mathrm{Si}-\mathrm{C}$ stretching vibrations and corresponding bending modes at 839 and 1465 (1332) $\mathrm{cm}^{-1}$, respectively, were observed. Furthermore, it can be seen that the characteristic silsesquioxane bands increase their intensity with the increasing POSS content. These results show that the POSS has been successfully incorporated into PU chain. It is confirmation that the POSS cube structure is chemically incorporated into the PU matrix rather than there being a physical mixture [32].

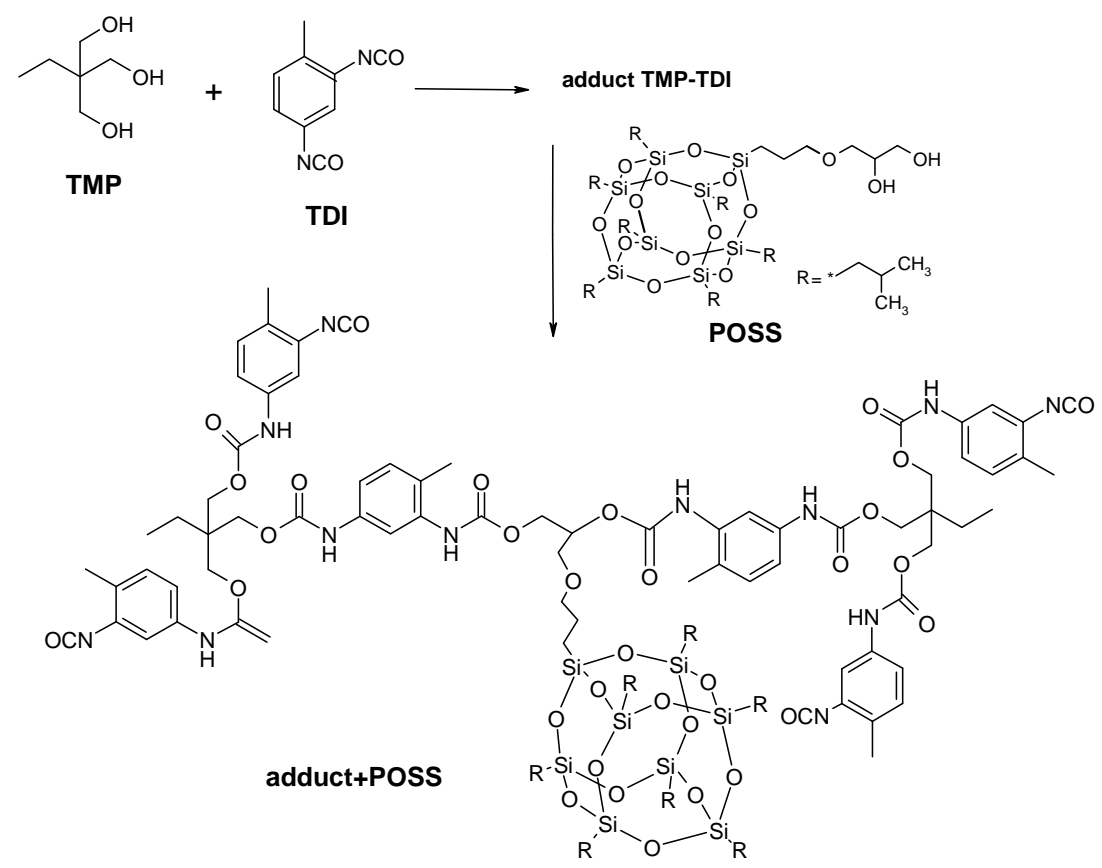

Fig. 2. The proposed structure of cured model adduct of TDI-TMP +POSS

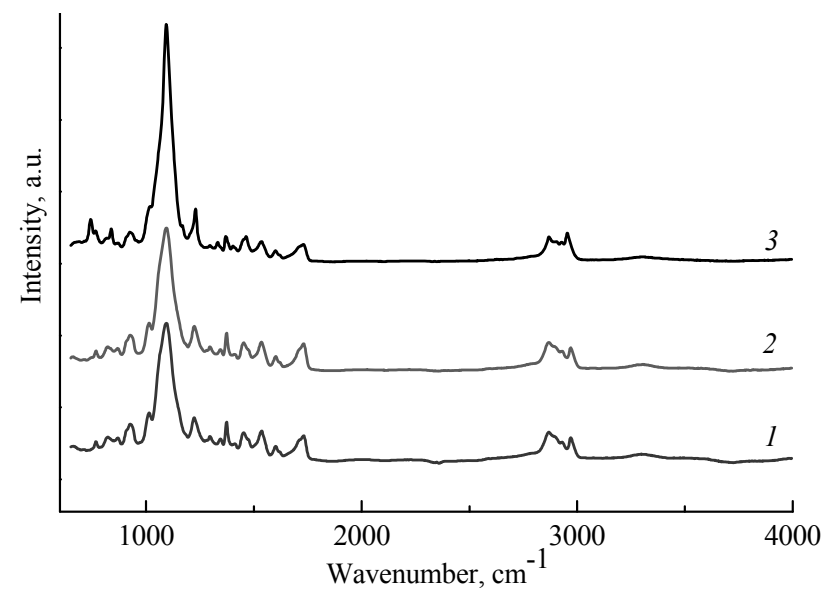

Fig. 3. FTIR spectra of: 1 - neat PU, 2-PU1, 3 - PU10 
The thermal behaviour of POSS-containing nanocomposites.

DSC thermograms of the PU/POSS nanocomposites (POSS content 1 and $10 \mathrm{wt}$ \%) as well as thermogram of the neat PU are presented in Fig. $4 a$.
Fig. $4 a$ shows the second DSC scans of the investigated samples. From the DSC data the glass transition temperature $\left(T_{\mathrm{g}}\right)$ of the nanocomposites was found to be increased with increasing of POSS content: from $T_{\mathrm{g}}=-61.13{ }^{\circ} \mathrm{C}$ (neat PU) to $T_{\mathrm{g}}=-59.76{ }^{\circ} \mathrm{C}$ and $T_{\mathrm{g}}=-58.76{ }^{\circ} \mathrm{C} \quad$ (PU1 and PU10, respectively).
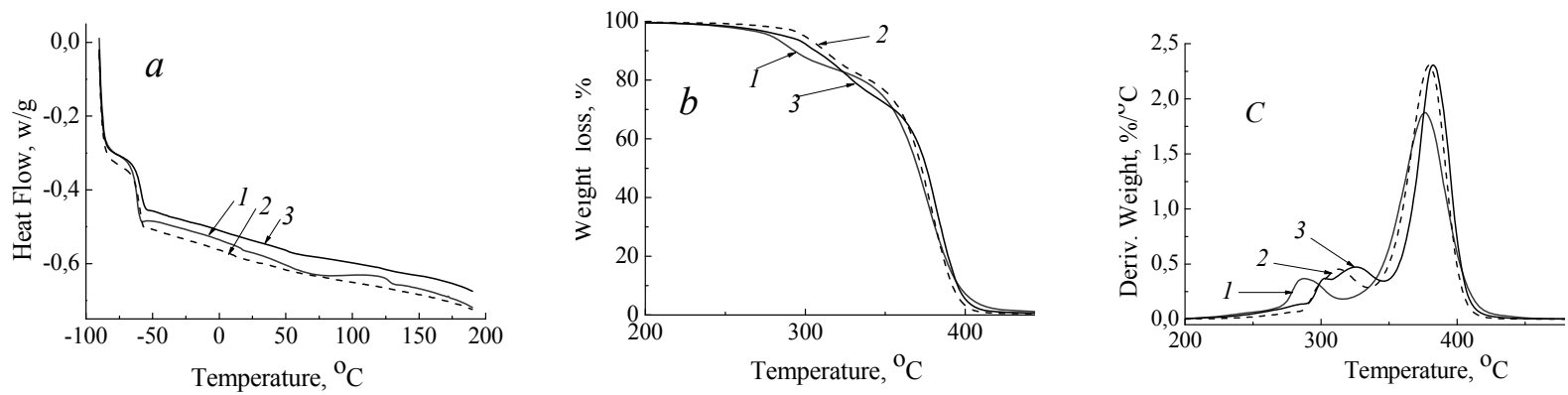

Fig. 4. DSC $(a)$ and TGA $(b, c)$ thermograms of neat $\mathrm{PU}$ and PU/POSS nanocomposites under inert atmosphere $\left(\mathrm{N}_{2}\right)$ at the heating rate of $20^{\circ} \mathrm{C} \cdot \mathrm{min}^{-1}$

The thermal behavior of PU/POSS nanocomposites was observed using TGA. The results of investigation are presented in Fig. 4 b, $c$. The TGA curves for all the samples displayed similar degradation profiles: for all the samples degradation was observed in two steps: around $280-300^{\circ} \mathrm{C}$ and above $380{ }^{\circ} \mathrm{C}$, indicative of the soft and hard segments in the polyurethane. Maximum values of the thermal decomposition temperatures, $T_{d(\max )}$, defined as the second maximum of the TGA curves, are shifted towards higher temperatures with increasing POSS content: from $376{ }^{\circ} \mathrm{C}$ for neat PU to 379 and $382^{\circ} \mathrm{C}$ for PU1 and PU10, respectively. According to the TGA data (Fig. $4 b$ ), addition of 1 wt. $\%$ of POSS results in increase in onset degradation temperature $\left(T_{\text {onset }}\right)$ from $270{ }^{\circ} \mathrm{C}$ for native PU to $294{ }^{\circ} \mathrm{C}$ for the nanocomposite.

Overall, the results of thermal properties investigation of POSS-containing nanocomposites demonstrate that the created nanocomposites are significantly more thermally stable in comparison with native polymer matrix (PU network). The thermal stability of the nanocomposites increases with amount of POSS in the systems.

The morphology of POSS-containing nanocomposites. Fig. 5 shows the SEM crosssectional images of the nanocomposites (fractured surfaces) with different POSS content in comparison with image of neat polymer matrix.

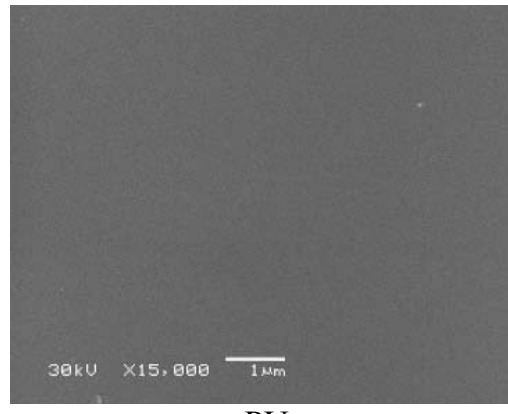

PU

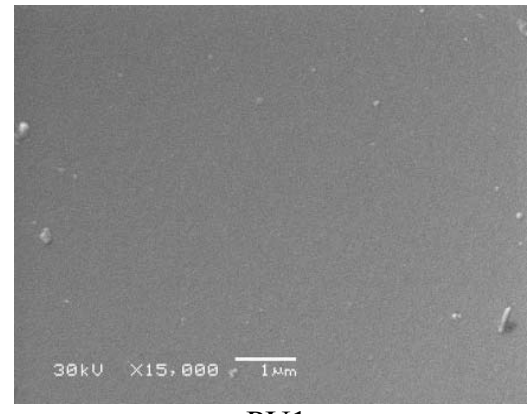

PU1

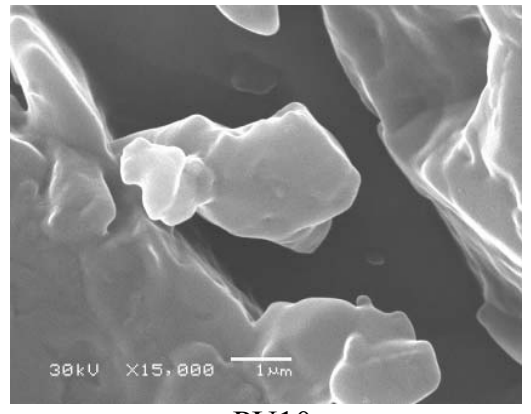

PU10

Fig. 5. SEM cross-sectional images of PU and PU/POSS nanocomposites (at magnification $\times 15000$ )

It has been found that comparatively homogeneous structure of neat PU matrix becomes more segregated in the nanocomposites with increasing POSS content. The POSS particles aggregation in the form of rectangular microdomains for PU10 with the maximum POSS 
content was observed. Obviously, the POSS introduced into PU matrix acts as a nanostructuring agent. As a result, the nanocomposites with more ordered structure are formed so leading to obtaining of materials with improved thermal stability.

\section{CONCLUSIONS}

The nanocomposites based on polyurethane matrix (PU) and 1,2-propanediolisobutyl polyhedral oligomeric silsesquioxane (POSS), using as a functionalized nanofiller, have been synthesized. The chemical structure, morphology, and thermal properties of the created nanocomposites have been investigated. The data obtained evidence that the POSS cube structure is chemically incorporated into the PU matrix during process of nanocomposites preparation. The incorporation of the POSS nanoparticles into PU matrix leads to the formation of more ordered structure, the POSS acts as a nanostructuring agent.

The incorporation of the POSS nanoparticles into PU matrix also significantly affects the thermal stability of the nanocomposites. The increasing in thermal stability of the nanocomposites with amount of POSS in the systems has been detected.

\section{ACKNOWLEDGEMENTS}

The authors thank the staffs of the Center of Collective Use of Scientific Equipments (CCUE) of NASU in IMC for DSC, TGA and N.G. Kholodny Institute of Botany of NASU for SEM measurements.

\title{
Синтез, морфологія та термічні властивості POSS-вмісних поліуретанових нанокомпозитів
}

\author{
Л.В. Карабанова, Л.А. Гончарова, В.І. Сапсай, Д.О. Климчук \\ Інститут хімії високомолекулярних сполук Національної академії наук України \\ Харківське шосе, 48, Київ, 02160, Україна, lyudmyla_karaban@ukr.net \\ Інститут ботаніки ім. М.Г. Холодного Національної академії наук України \\ вул. Терещченківська, 2, Київ, 01601, Україна
}

\begin{abstract}
Синтезована серія нанокомпозитів на основі поліуретанової матриці (ПУ) із використанням 1,2-пропандіолізобутилполіедрального олігомерного сілсесквіоксану (POSS) як функціонального нанонаповнювача. Досліджено вплив вмісту POSS на структуру та властивості створених нанокомпозитів. Полімерна матриия (ПУ сітка) синтезована на основі адукту триметилолпропану (ТМП), толуїлен-2,4діізоцианату (ТДІ) та олігоетергліколю з $\mathrm{Mw}=5000$ г/моль-1. Модельна система на основі адукту ТМП з ТДI була використана для дослідження можливості вбудовування POSS в поліуретанову сітку із застосуванням FTIR спектроскопї. Структура та морфологія POSS-вмісних нанокомпозитів досліджена методами FTIR-ATR спектроскопї̈ та SEM. Термічні властивості досліджені методами ДСК та ТГА. Показано, щуо введення POSS в ПУ матриџю призводить до підвищення термічної стабільності створених нанокомпозитів.
\end{abstract}

Ключові слова: поліуретан, поліедральний олігомерний сілсесквіоксан, нанокомпозит, морфологія, Фур'є інфрачервона спектроскопія, диференційна скануюча калориметрія, термогравіметричний аналіз 


\title{
Синтез, морфология и термические свойства POSS-содержащих полиуретановых нанокомпозитов
}

\author{
Л.В. Карабанова, Л.А. Гончарова, В.И. Сапсай, Д.А. Климчук
}

\author{
Институт химии высокомолекулярных соединений Национальной академии наук Украины \\ Харьковское шоссе, 48, Киев,02160, Украина, lyudmyla_karaban@ukr.net \\ Институт ботаники им.Н.Г. Холодного Наџиональной академии наук Украинь \\ ул. Терещенковская, 2, Киев, 01601, Украина
}

\begin{abstract}
Синтезирована серия нанокомпозитов на основе полиуретановой матриць (ПУ) с использованием 1,2-пропандиолизобутилполиэдрального олигомерного силсесквиоксана (POSS) как функиионального нанонаполнителя. Исследовано влияние содержания POSS на структуру и свойства созданных нанокомпозитов. Полимерная матрица (ПУ сетка) синтезирована на основе аддукта триметилолпропана (ТМП), толуилен-2,4-диизочианата (ТДИ) и олигоэфиргликоля с $M w=5000$ г/моль-1. Модельная система на основе аддукта ТМП с ТДИ была использована для исследования возможности встраивания POSS в полиуретановую сетку с применением FTIR спектроскопии. Структура и морфология POSS-содержаших нанокомпозитов исследована методами FTIR-ATR спектроскопии и SEM. Термические свойства исследованы методами ДСК и ТГА. Показано, что введение POSS в ПУ матрииу приводит к повышению термической стабильности созданньх нанокомпозитов.
\end{abstract}

Ключевые слова: полиуретан, полиэдральный олигомерный силсесквиоксан, нанокомпозит, морфология, Фурье инфракрасная спектроскопия, дифференцииальная сканирующая калориметрия, термогравиметрический анализ

\section{REFERENCES}

1. Ray S.S., Okamoto M. Polymer/layered silicate nanocomposites: a review from preparation to processing. Prog. Polym. Sci. 2003. 28(11): 1539.

2. Shaffer M.S.P., Sandler J.K.W. Processing and properties of nanocomposites. In: Carbon Nanotube/Nanofibre Polymer Composites. (Singapore: World Scientific, 2006).

3. Bershtein V.A., Gun ko V.M., Karabanova L.V., Sukhanova T.E., Yakushev P.N., Egorova L.M., Turova A.A., Zarko V.I., Pakhlov E.M., Vylegzhanina M.E., Mikhalovsky S.V. Polyurethane-poly(2-hydroxyethyl methacrylate) semi-IPN-nanooxide composites. RSC Adv. 2013. 3: 14560.

4. Karabanova L.V., Bershtein V.A., Sukhanova T.E., Yakushev P.N., Egorova L.M., Lutsyk E.D., Svyatyna A.V., Vylegzhanina M.E. 3D diamond-containing nanocomposites based on hybrid polyurethane-poly(2-hydroxyethyl methacrylate) semi-IPNs: Composition-nanostructure-segmental dynamics-elastic properties relationships. J. Pol. Sci. 2008. B 46(16): 1696.

5. Moniruzzaman M., Winey K.I. Polymer nanocomposites containing carbon nanotubes. Macromolecules. 2006. 39(16): 5194.

6. Wolinska-Grabczyk A., Jankowski A. Gas transport properties of segmented polyurethanes varying in the kind of soft segments. Sep. Purif. Technol. 2007. 57(3): 413.

7. Gumenna M.A., Shevchuk A.V., Klimenko N.S., Shevchenko V.V. Polyurethanes on the base of polyhedral oligosilsesquioxanes (POSS). Polymer Journal. 2007. 29(3): 177. [in Russian].

8. Karabanova L.V., Whitby R.L.D., Bershtein V.A., Korobeinyk A.V., Yakushev P.N., Bondaruk O.M., Lloyd A.W., Mikhalovsky S.V. The role of interfacial chemistry and interactions in the dynamics of thermosetting polyurethane-multi-walled carbon nanotube composites with low filler content. Colloid Polym. Sci. 2013. 291(3): 573.

9. Karabanova L.V., Whitby R.L., Bershtein V.A., Korobeinyk A.V., Yakushev P.N., Bondaruk O.M., Lloyd A.W., Mikhalovsky S.V. Microstructure changes of polyurethane by inclusion of chemically modified carbon nanotubes at low filler contents. Compos. Sci. Technol. 2012. 72(8): 865.

10. Madhavan K., Reddy B.S.R. Structure-gas transport property relationships of poly(dimethylsiloxane-urethane) nanocomposite membranes. J. Membr. Sci. 2009. 342(1-2): 291.

11. Fomenko A.A., Gomza Yu.P., Klepko V.V., Gumenna M.A., Klimenko N.S., Shevchenko V.V. Dielectric properties, conductivity and structure of urethane composites based on polyethylene glycol and polyhedral silsesquioxane. Polymer Journal. 2009. 31(2): 137. [in Ukrainian]. 
12. Mahapatra S.S., Yadav S.K., Cho J.W. Nanostructured hyperbranched polyurethane elastomer hybrids that incorporate polyhedral oligosilsesquioxane. React. Funct. Polym. 2012. 72(4): 227.

13. Lewicki J.P., Pielichowski K., Jancia M., Hebda E., Albo R.L.F., Maxwell R.S. Degradative and morphological characterization of POSS modified nanohybrid polyurethane elastomers. Polym. Degrad. Stab. 2014. 104: 50.

14. Wei K, Wang L, Zheng S. Organic-inorganic polyurethanes with 3, 13-dihydroxypropyloctaphenyl doubledecker silsesquioxane chain extender. Polym. Chem. 2013. 4:1491.

15. Bourbigot S., Turf T., Bellayer S., Duquesne S. (2009) Polyhedral oligomeric silsesquioxane as flame retardant for thermoplastic polyurethane. Polym. Degrad. Stab. 2009. 94:1230.

16. Huang J., Jiang P., Li X., Huang Y. Synthesis and characterization of sustainable polyurethane based on epoxy soybean oil and modified by double-decker silsesquioxane. J. Mater. Sci. 2016. 51(5): 2443.

17. Wang W., Guo Y., Otaigbe J.U. The synthesis, characterization and biocompatibility of poly(ester urethane)/polyhedral oligomeric silesquioxane nanocomposites. Polymer. 2009. 50(24): 5749.

18. Lai Y.S., Tsai C.W., Yang H.W., Wang G.P., Wu K.H. Structural and electrochemical properties of polyurethanes/polyhedral oligomeric silsesquioxanes (PU/POSS) hybrid coatings on aluminum alloys. Mater. Chem. Phys. 2009. 117(1): 91.

19. Huitron-Rattinger E., Ishida K., Romo-Uribe A., Mather P. T. Thermally modulated nanostructure of poly $(\varepsilon-$ caprolactone)-POSS multiblock thermoplastic polyurethanes. Polymer. 2013. 54(13): 3350.

20. Karabanova L.V., Boiteux G., Gain O., Seytre G., Sergeeva L.M., Lutsyk E.D. Miscibility and thermal and dynamic mechanical behaviour of semi-interpenetrating polymer networks based on polyurethane and poly(hydroxyethyl methacrylate). Polym. Int. 2004. 53(12): 2051.

21. Wamke A., Dopierała R., Prochaska K., Maciejewski H., Biadasz A., Dudkowiak A. Characterization of Langmuir monolayer, Langmuir-Blodgett and Langmuir-Schaefer films formed by POSS compounds. Colloids Surf. A. 2015. 464: 110.

22. Jerman I., Kozelj M., Orel B. The effect of polyhedral oligomeric silsesquioxane dispersant and low surface energy additives on spectrally selective paint coatings with self-cleaning properties. Solar Energy Materials \& Solar Cells. 2010. 94(2): 232;

23. Jerman I., Mihelcic M., Verhovsek D., Kovac J., Orel B. Polyhedral oligomeric silsesquioxane trisilanols as pigment surface modifiers for fluoropolymer based Thickness Sensitive Spectrally Selective (TSSS) paint coatings. Solar Energy Materials \& Solar Cells. 2011. 95(2): 423.

24. Kraus-Ophir S., Jerman I., Orel B., Mandler D. Symmetrical thiol functionalized polyhedral oligomeric silsesquioxanes as building blocks for LB films. Soft Matter. 2011. 7: 8862.

25. Dittmar U., Hendan B.J., Florke U., Marsmann H.C. Funktionalisierte Octa-(propylsilsesquioxane) (3$\left.\mathrm{XC}_{3} \mathrm{H}_{6}\right)_{8}\left(\mathrm{Si}_{8} \mathrm{O}_{12}\right)$ Modellverbindungen für oberflächenmodifizierte Kieselgele. J. Organomet. Chem. 1995. 489(1-2): 185 .

26. Bärtsch M., Bornhauser P., Calzaferri G., Imhof R., $\mathrm{H}_{8} \mathrm{Si}_{8} \mathrm{O}_{12}$ : A model for the vibrational structure of zeolite A. J. Phys.Chem. 1994. 98(11): 2817.

27. Xue M., Zhang X., Wu Z., Wang H., Ding X., Tian X. Preparation and flame retardancy of polyurethane/POSS nanocomposites. Chin. J. Chem. Phys. 2013. 26(4): 445.

28. Maoz R., Sagiv, Degenhardt J.D., Mohwald H., Quint P. Hydrogen-bonded multilayers of self-assembling silanes: structure elucidation by combined Fourier transform infra-red spectroscopy and X-ray scattering techniques. Supramol. Sci. 1995. 2(1): 9.

29. Bellamy L.J. The infrared spectra of complex molecules. V. 2. Advances in infrared group frequencies. (London: Methuen, 1980).

30. Moon J.H., Seo J.S., Xu.Y., Yang S. Direct fabrication of 3D silica-like microstructures from epoxyfunctionalized polyhedral oligomeric silsesquioxane (POSS). J. Mater. Chem. 2009. 19(27): 4687.

31. Smetankina N.P., Angelova A.V., Lukas S.D. Polyurethane coatings based on polyoxypropylene glycols. Synthesis and physical chemistry of polyurethanes. 1967. 5: 49. [in Russian].

32. Zhang S., Zou Q., Wu L. Preparation and characterization of polyurethane hybrids from reactive polyhedral oligomeric silsesquioxanes. Macromol. Mater. Eng. 2006. 291(7): 895. 